\title{
TYPES OF TOLERANT INTERACTION OF PRIMARY SCHOOL TEACHERS WITH STUDENTS
}

\section{Anna Lyulka ${ }^{1}$}

DOI: https://doi.org/10.30525/978-9934-588-52-5-7

Much of modern pedagogical technology is based on the ideas of collaborative pedagogy. Cooperation itself saturates the educational process with mutual orientation, joy of knowledge, success, mutual respect and mutual understanding as manifestations of tolerance.

Education of tolerant relationships belongs to the field of formation of social communications. Their indicators are: the ability to take responsibility and control their own actions; the ability to express an adequate emotional response to events; desire to understand other people on the basis of mastering information [2, p. 16].

The attitude to interaction develops in each child as a quality of his/her personality. The teacher consolidates the relationship with children by educating them in the skills of cooperation, creating situations in the classroom and practicing cooperation in the learning process.

Tolerant interaction of primary school teachers with students is most evident in the process of building dialogue, cooperation and guardianship.

The main function of dialogic interaction is to stimulate the individual's ability to self-development and self-realization, as well as the development of creative potential with a focus on individual abilities, experience, character and level of needs. Peculiarities of educational dialogue as a type of tolerant interaction are: equality of positions of student and teacher; absence of assessment, full acceptance of the student as he/she is; special emotional color of communication; sincerity and naturalness in the expression of emotions. This characteristic of dialogic interaction is the foundation of tolerance and tolerant beliefs [5, p. 111].

In the process of dialogue there is a development of independence and critical thinking, initiative and students' own position, the desire to discuss and solve the problem posed for them. A dialogue teaches students to think, reason, compare, analyze and synthesize the information obtained. Particular attention should be paid to the dialogical position of the teacher: tolerant attitude to different views of students, willingness to take mutually exclusive views on the problem and find a collegial solution of it based on the evidence and argumentation of the positions of dialogue participants [3, p. 45].

${ }^{1}$ V. G. Korolenko National Pedagogical University of Poltava, Ukraine 
The second type of tolerant interaction, tht is cooperation, is conditioned by the transfer of the educational process to the level of personal interaction. It most effectively promotes the development of students as subjects of activity and the formation of tolerant interaction in general, as the category of «cooperation» is a complex unity:

a) forms of long-term relationship are based on mutual understanding, mutual experience;

b) ways of organizing joint activities «on an equal footing», which involves manifestations of independence, activity and organization;

c) such forms of interaction between a teacher and students, when joint work is based on mutual support and mutual assistance, that is the ability of students to work together with each other and with the teacher in combining efforts and coordinating their actions;

d) active-positive, humanistic style of relations between students and teachers in the performance of educational tasks; mutual trust, friendliness, mutual assistance in case of difficulties and learning failures [1, p. 39].

Due to mutual understanding, equality of personal positions of all participants begin to develop. in the pedagogical process. A teacher and a student as subjects should interact and be partners and comrades.

Cooperation takes various forms, such as complicity, community, cocreation, empathy and co-management. Depending on the type of the academic subject discipline and methodological requirements, the approach to cooperation between a teacher and a student may change. In order for it to happen, it is very important to have positive emotions and relationships. In the process of pedagogical interaction, the teacher creates conditions for motivating students through an individual approach. With a friendly and respectful attitude to the personality of each student, it is very important for the teacher to be able to make the child understand its uniqueness [4, p. 6].

Guardianship as a type of pedagogical interaction is also correlated with the concept of tolerance. Guardianship involves care, and this care does not degrade the dignity of the guardian. Its signs are emotional stability, a high level of empathy, social activity, desire to come to the rescue, extroversion.

All types of tolerant pedagogical interaction considered above are interconnected. Most often, they accompany each other, and with the change of conditions mutually interchange.

Thus, certain type of tolerant interaction corresponds to certain educational conditions: dialogue, cooperation or guardianship. The variety of situations and their rapid changeability determine the dynamics of the nature of teacher interaction with younger students. 


\section{References:}

1. Achasova, L. Yu. (2015). Spetsyfyka tolerantnoho vzaymodeistvyia subъektov obrazovatelnoho prostranstva v uslovyiakh shkoli [The specifics of tolerant interaction of subjects of the educational space in the school]. Pedahohycheskoe obrazovanye $i$ nauka, no. 5, pp. 38-40.

2. Druzhynyna, A. E. (2017). Formyrovanye tolerantnikh otnoshenyi v obrazovatelnom prostranstve [Formation of tolerant relations in the educational space]. Vospytanye shkolnykov, no. 1, pp. 15-18.

3. Zhmykhova, I. B. (2018). Tolerantna pedahohika v osvitnomu ta vykhovnomu prostori shkoly [Tolerant pedagogy in the educational space of the school]. Vykhovna robota $v$ shkoli, no. 6, pp. 41-47.

4. Kazakova, S. (2019). Pedahohichna tolerantnist uchytelia pochatkovykh klasiv [Pedagogical tolerance of primary school teachers]. Pedahohichna maisternia, no. 4, pp. 5-8.

5. Orlovska, N. (2017). Shkola tolerantnosti: kroky stanovlennia [School of tolerance: steps of formation]. Dyrektor shkoly, litseiu, himnazii, no. 3/4, pp. 107-117.

\section{EDUCATION PROGRAMS OF PROFESSIONAL ENGLISH COURSE FOR MANAGEMENT STUDENTS IN UKRAINIAN ENVIRONMENT: COMPETENCE APPROACH}

\section{Roliak Angelina ${ }^{1}$}

DOI: https://doi.org/10.30525/978-9934-588-52-5-8

Modern development of the foreign language component in any professional environment (including management branch) leads to the necessity of educational programs modernization and standardization [2, p. 9]. So we conduct our research taking account of these two aspects.

Our analysis demonstrates that in the result of the post-modern reforms, education programs of professional English language course (including management specialties) in Ukrainian institutions of high learning are rather homogeneous and consist of the typical parts, among which are the following: the purpose of the discipline; the discipline description; the results of education; evaluation criteria; evaluation tools; the discipline program; themes of practical classes; forms of current and final control; tools, equipment and software used in the academic discipline; recommended sources of information [6, p. 16].

The purpose of teaching a foreign language course in a non-linguistic high educational institution (management belongs to this division) is to develop the

\footnotetext{
${ }^{1}$ State Agrarian and Engineering University in Podilya, Ukraine
} 